\title{
Over-expression of GLUT4 selectively in adipose tissue in transgenic mice: implications for nutrient partitioning
}

\author{
BY LUIGI GNUDI ${ }^{1}$, PETER R. SHEPHERD ${ }^{2}$ AND \\ B ARBARA B. KAHN ${ }^{1 *}$ \\ ${ }^{1}$ The Harvard Thorndike Research Laboratory and Department of Medicine, Harvard Medical \\ School and Beth Israel Hospital, Boston, MA 02215, USA \\ ${ }^{2}$ Department of Clinical Biochemistry, University of Cambridge, Cambridge
}

\section{Surexpression sélective de GLUT4 dans le tissu adipeux chez des souris transgéniques: implications pour la répartition des nutriments}

\section{RÉSUMÉ}

La captation du glucose dans le muscle, et à un moindre degré, dans le tissu adipeux est importante pour le maintien de l'homéostase du glucose. La stimulation défectueuse de l'insuline pour transporter le glucose dans ces tissus est une caractéristique pathogène importante des situations de résistance à l'insuline chez l'homme et chez l'animal. Les études récentes du clonage des molécules ont révélé une famille de protéines transportant le glucose responsable de la diffusion facilitée du glucose dans les cellules de mammifère. Les transporteurs du glucose GLUT4 sont l'isoforme prédominante exprimée dans le muscle et la graisse. En l'absence d'insuline cette isoforme est séquestrée dans la cellule, mais après la stimulation de l'insuline elle est rapidement déplacée vers la surface de la cellule, ce qui provoque une augmentation du transport du glucose. On pense que ce mécanisme est responsable de la plus grande partie de l'effet de stimulation de l'insuline sur le transport du glucose dans le muscle et le tissu adipeux.

Les niveaux de GLUT4 sont régulés de façon différente dans le muscle et dans le tissu adipeux. Dans l'obésité et le diabète, l'expression génétique de GLUT4 est réduite de façon prononcée dans le tissu adipeux, alors qu'elle est très peu affectée dans le muscle. De plus, dans au moins quelques formes d'obésité, l'expression de GLUT4 dans le tissu adipeux change avec les différents stades de l'obésité. Les niveaux des transporteurs du glucose dans le muscle et le tissu adipeux peuvent aussi être régulés par une manipulation diététique, et là encore un effet différent est observé entre le muscle et la graisse, les niveaux de GLUT4 dans le tissu adipeux étant affectés les plus spectaculairement. Ces altérations dans l'expression de GLUT4 sont associées à des modifications dans le flux du glucose dans le tissu adipeux, conduisant ainsi à l'hypothèse que le niveau de l'expression de GLUT4 joue un rôle dans le développement du tissu adipeux et dans la physiopathologie de l'obésité. Nous avons utilisé une approche transgénique pour déterminer si la surexpression sélective de GLUT4 peut affecter l'adiposité et l'homéostase du glucose dans le corps tout entier.

Glucose is essential for the survival of mammalian cells, but as it is impermeable to cell membranes it requires transport systems to enter the cell. Two separate mechanisms of glucose transport have been identified. In kidney and gut an active energy-dependent

\footnotetext{
* For reprints.
} 
$\mathrm{Na}^{+}$-glucose co-transport system exists which allows transport of glucose against concentration gradients (Albert et al. 1989). However, the most common mechanism of glucose transport in mammalian cells is a facilitated diffusion system whereby glucose is transported down a concentration gradient. Recent molecular-cloning studies have identified a family of closely-related membrane proteins which are responsible for facilitated diffusion of glucose into mammalian cells (Bell et al. 1990; Kahn, 1992; Waddell et al. 1992). To date six genes that code functional facilitated diffusion glucose transporter proteins have been identified and these have been designated GLUT1-5 and GLUT7 (Bell et al. 1990; Kahn, 1992; Waddell et al. 1992). These glucose-transportergene products have different intracellular distributions and kinetic properties and are expressed in a tissue-specific manner which, taken together, suggest a specialized role for each isoform. GLUT4 is the predominant isoform expressed in skeletal muscle, heart and adipose tissue and is responsible for the ability of insulin to greatly stimulate glucose transport into those tissues (Bell et al. 1990; Thorens et al. 1990; Kahn, 1992). In unstimulated cells most GLUT4 is sequestered in intracellular pools and the rate of glucose transport into the cell is low. However, following insulin stimulation large amounts of GLUT4 are translocated to the plasma membrane, resulting in increased glucose transport (Kahn, 1992).

Most insulin-stimulated glucose disposal from the bloodstream is accounted for by increased rates of glucose transport into muscle, and to a lesser extent adipose tissue (DeFronzo, 1988). The ability of insulin to stimulate glucose transport into muscle and adipose tissue is impaired in obesity, non-insulin-dependent diabetes (NIDDM) and insulin-dependent diabetes (IDDM) resulting in decreased blood glucose disposal rates (Butler et al. 1990; Yki-Jarvinen et al. 1990). Glucose transport is the rate-limiting step for glucose utilization in muscle and adipose tissue under most physiological conditions in normal subjects (Yki-Jarvinen et al. 1987; Katz et al. 1988; Fink et al. 1992), in NIDDM (Yki-Jarvinen et al. 1990; Rothman et al. 1992), in IDDM (Yki-Jarvinen et al. 1990) and insulin-deficient diabetic rats (Zeil et al. 1988). Therefore, it seems most likely that the defect in insulin-stimulated glucose disposal would lie at the level of the ability of insulin to stimulate glucose transport.

\section{ROLE OF GLUT4 LEVELS IN MUSCLE AND FAT IN THE DEVELOPMENT OF OBESITY AND INSULIN RESISTANCE}

Impaired insulin-stimulated glucose transport into muscle and adipose tissue could be due to defects in the intracellular signalling mechanisms of insulin, leading to altered glucose-transporter translocation, fusion with the plasma membrane, or activation. Alternatively, reduced insulin-stimulated glucose transport could be due to a decrease in the expression of glucose transporters (Kahn, 1992). Evidence suggests that both these mechanisms may contribute to insulin resistance in obesity and diabetes in animal models and in human subjects (Shepherd \& Kahn, 1993).

A commonly-studied animal model of insulin resistance is the Zucker rat which when homozygous for the $f a$ gene exhibits obesity and insulin resistance (Penicaud et al. 1987). Longitudinal studies have been carried out to analyse levels of GLUT4 in muscle and fat of Zucker rats, and it was observed that GLUT4 levels are similar in muscle from obese falfa Zucker rats and lean -1- Zucker rats at all ages studied (Friedman et al. 1991; Brozinick et al. 1992; Kahn \& Pedersen, 1992). Therefore, the decreased ability of 
insulin to stimulate glucose transport into muscle from the obese falfa Zucker rats is most probably due to the decreased insulin-induced recruitment of glucose transporters to the plasma membrane (Brozinick et al. 1992; King et al. 1992). In contrast to muscle, the ability of insulin to stimulate glucose transport into adipocytes of Zucker rats closely matches the level of GLUT4 expression in adipose tissue. GLUT4 levels and insulinstimulated glucose transport are elevated in adipocytes from younger pre-obese $f a / f a$ animals, while both are decreased in parallel in adipocytes of the older obese $f a / f a$ animals (Hainault et al. 1991; Pedersen et al. 1992).

Obesity and insulin resistance can be induced also in normal rats by causing lesions of the ventromedial hypothalamus (VMH), either by using surgical intervention or administering gold thioglucose. The patterns of glucose-transporter expression and insulin responsiveness in muscle and fat during the development of obesity in VMHlesioned rats follows a pattern similar to that seen in Zucker rats. GLUT4 levels are not decreased in muscle from obese insulin-resistant VMH-lesioned animals, while GLUT4 expression and insulin-stimulated glucose transport in adipocytes is initially elevated and then decreases with the progression of the obese state (Cousin et al. 1992). Further, a similar pattern of GLUT4 expression is seen with intracerebroventricular administration of neuropeptide Y (NPY) to rats (Zarjevski et al. 1994).

Therefore, while GLUT4 levels in muscles are not different from those of control animals, GLUT4 levels in adipocytes from VMH-lesioned rats, Zucker rats and rats administered NPY are elevated in the early stages of developing obesity, and this is associated with normal or elevated insulin-stimulated glucose disposal. This suggests that elevated GLUT4 levels in adipocytes may initially compensate for insulin resistance in muscle and, further, may alter the partitioning of glucose between muscle and adipose tissue, thus leading to the development of increased adiposity and eventually to obesity.

\section{TRANSGENIC OVER-EXPRESSION OF GLUT4 IN ADIPOSE TISSUE}

To address the role of adipose tissue GLUT4 levels in the maintenance of whole-body glucose homeostasis and development of obesity we have developed a transgenic mouse model which selectively over-expresses GLUT4 in fat tissue (Shepherd et al. 1993). Two transgenic lines were generated, both of which selectively over-expressed GLUT4 in fat, at least 9-fold in white fat, and 4-5-fold in brown fat (Shepherd et al. 1993). Intraperitoneal glucose tolerance tests performed on transgenic mice and their nontransgenic littermates revealed that the transgenic mice had an increased rate of whole-body glucose disposal (Shepherd et al. 1993). This was associated with lower insulin levels, indicating the GLUT4-over-expressing animals were more insulin sensitive than control animals (Shepherd et al. 1993).

To understand better the basis for these differences, in vitro glucose transport studies were carried out. Experiments were performed in the presence of tracer glucose concentrations $(3 \mu \mathrm{M})$ to ensure that glucose transport was rate-limiting for metabolism. Over-expression of GLUT4 in fat had no effect on basal or insulin-stimulated glucose transport into isolated soleus muscle. However, in isolated adipocytes from transgenic animals basal rates of glucose transport were elevated $20-30$-fold over basal rates in adipocytes from non-transgenic animals and approximately 1.5 -fold over insulinstimulated rates compared with non-transgenic mice. This high rate of basal glucose 


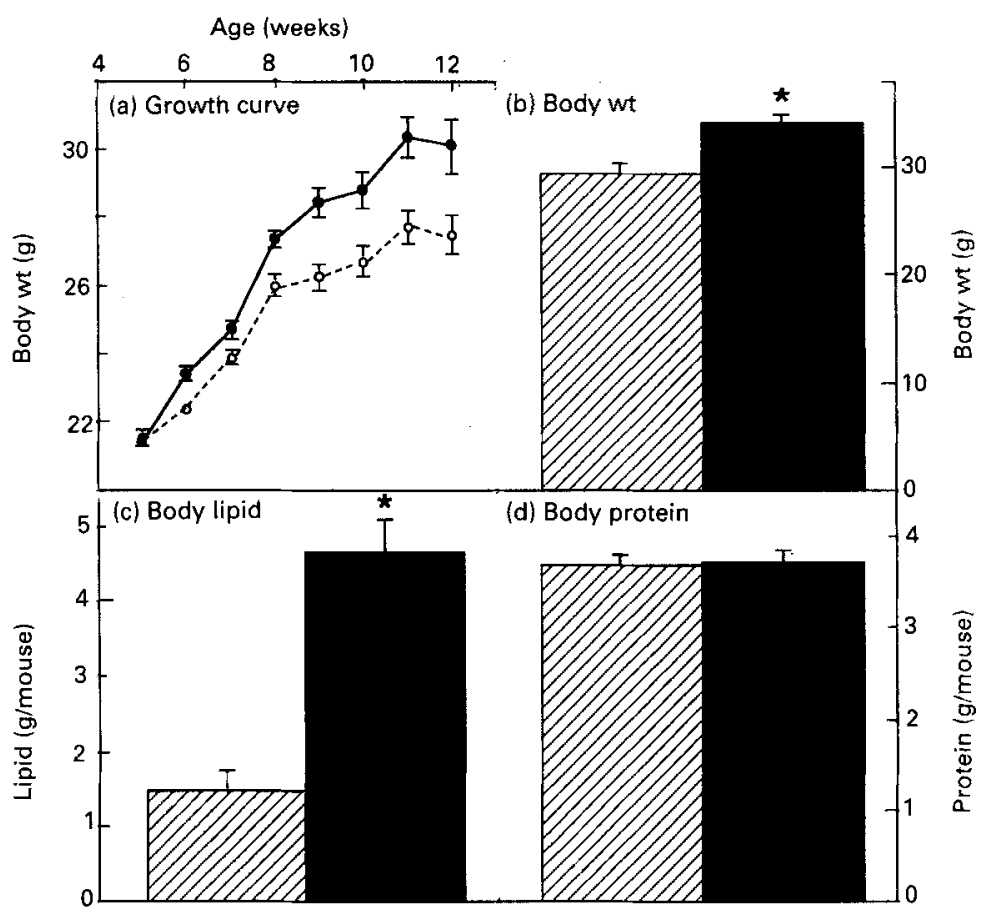

Fig. 1. Adiposity characteristics in mice heterozygous for the transgene $(-; m)$ and for non-transgenic $(\mathrm{O}--\mathrm{O} ; \mathrm{Z})$ littermates. Results are expressed as the means with their standard errors represented by vertical bars, $* P<0.02$. (From Shepherd et al. 1993. Reproduced with permission from the American Society for Biochemistry and Molecular Biology.)

transport in adipocytes from transgenic animals was further stimulated approximately 4-fold by insulin treatment (Shepherd et al. 1993; Tozzo et al. 1995).

We were interested also to determine if this massive flux of glucose into adipocytes would have an effect on body composition. No difference in weight was observed between transgenic and non-transgenic animals up to the age of 5 weeks. However, after this age the transgenic animals began to gain weight more rapidly (Fig. 1). Weight gain plateaued at about 12 weeks of age, at which time transgenic animals were approximately 3-4 g (i.e. approximately $10 \%$ ) heavier than their non-transgenic littermates. No statistical difference in food intake was observed between transgenic and non-transgenic animals during this phase of weight gain (Shepherd et al. 1993).

The observed increase in body weight was found to be totally accounted for by increased body lipid, with the lipid content of transgenic animals being approximately $15 \% v$. approximately $5 \%$ for non-transgenic animals (Fig. 1). To understand the basis for this increased adiposity, fat cell size was determined in adipocytes isolated from several different depots. No significant difference in fat cell size was detected between transgenic and non-transgenic animals in any of the depots tested (i.e. perirenal, perigonadal, omental or subcutaneous) up to 6 months of age. This indicated that the increased adiposity was due largely to adipocyte hyperplasia rather than hypertrophy. Estimation of fat cell number in epididymal fat pads indicated greater than a 2 -fold increase in transgenic mice. 
High-fat feeding in human subjects (Swinburn et al. 1991) and rodents (Kraegen et al. 1986) is associated with in vivo insulin resistance and a reduction in insulin-stimulated glucose transport into muscle and adipocytes in vitro. This insulin resistance is associated with reduced expression of GLUT4, especially in fat (Kahn \& Pedersen, 1992). Therefore, we were interested to determine whether the down-regulation of GLUT4 in adipose tissue, that was usually induced by high-fat feeding, could be prevented by driving GLUT4 expression with a heterologous promoter as we did in the transgenic mice over-expressing GLUT4 specifically in fat. If this was the case, we were interested in determining whether the elevated levels of GLUT4 in adipose tissue could ameliorate the insulin resistance associated with the high-fat diet.

After weaning at $21 \mathrm{~d}$ of age mice were fed $a d$ lib. for $12-15$ weeks with either a low-fat $\operatorname{diet}$ (\% energy supplied; 10 fat, 69 carbohydrate, 21 protein) or a high-fat diet (\% energy supplied; 55 fat, 24 carbohydrate, 21 protein). In both diets the energy from carbohydrates was about two-thirds complex sugars and one-third simple sugars, while the fats in both diets contained approximately $300 \mathrm{mg}$ saturated fats/g fat. The low-fat diet had an energy content of $15 \mathrm{~kJ} / \mathrm{g}$, while the energy content of the high-fat diet was $20 \mathrm{~kJ} / \mathrm{g}$. Both diets were supplemented with vitamins and minerals, and mice on both diets consumed the same amount of energy.

The high-fat diet caused a 50\% reduction in GLUT4 expression in white adipose tissue of non-transgenic mice (Fig. 2). The ability of insulin to stimulate in vitro glucose transport in adipocytes isolated from non-transgenic animals was also reduced by $60 \%$ (Fig. 3). These results are in agreement with previous observations in rats (Pedersen et al. 1991). However, in transgenic mice on the high-fat diet, GLUT4 levels in white adipose tissue were still 30-fold elevated compared with non-transgenic animals on the high-fat diet (Fig. 2). Further, the high-fat diet did not affect the elevated basal or insulin-stimulated glucose transport rates into adipocytes isolated from transgenic animals (Fig. 3). Despite the continued over-expression of GLUT4 and maintenance of high glucose transport rates into adipocytes of transgenic animals on the high-fat diet, both transgenic and non-transgenic mice showed similarly impaired ability to dispose of an intraperitoneal glucose load, although plasma insulin levels tended to be lower in the transgenic animals (Gnudi et al. 1995). Thus, over-expression of GLUT4 in adipose tissue could not overcome the insulin resistance which develops also in muscle and liver with high-fat feeding.

Transgenic mice on a low-fat diet showed a marked increase in adiposity when compared with non-transgenic animals on the same diet, although fat cell sizes in the two groups of animals were not different. These findings are in agreement with previous comparisons between these two groups of animals when fed on a standard laboratory chow (Shepherd et al. 1993). As expected, high-fat feeding in the non-transgenic animals caused a marked increase in adiposity and a $65 \%$ increase in fat cell size when compared with non-transgenic animals on a low-fat diet (Pedersen et al. 1991). The surprising result from these studies was that transgenic mice fed on the high-fat diet did not increase body lipid content or fat cell size despite having a very similar energy intake to non-transgenic mice on the high-fat diet (Gnudi et al. 1995).

Our most recent studies begin to suggest how this might come about. We have investigated the effects of GLUT4 over-expression in adipose tissue on the rate-limiting step for the uptake of fatty acids into tissues, i.e. lipoprotein lipase (EC 3.1.1.34; LPL) 


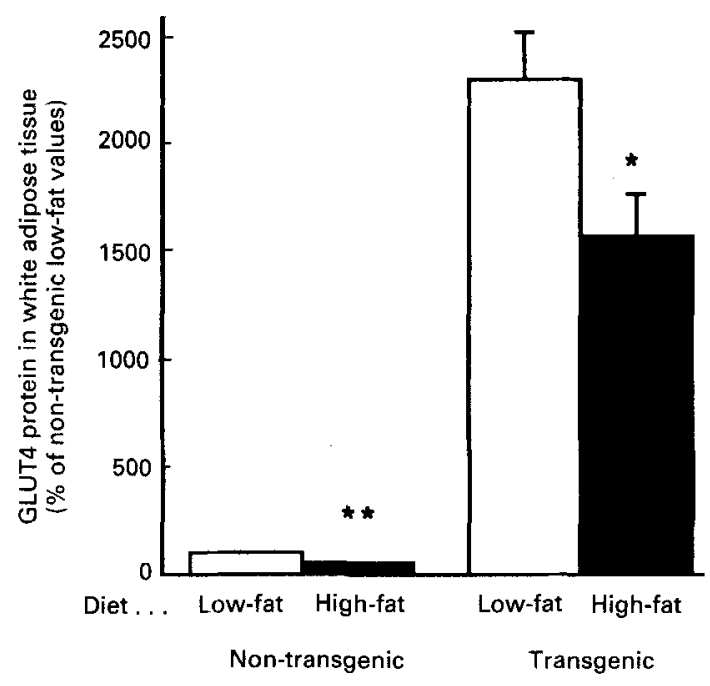

Fig. 2. GLUT4 protein levels in white adipose tissue from non-transgenic and transgenic mice fed on either a low-fat or high-fat diet. The results are expressed as a percentage of the intensity of the band for GLUT4 in white adipose tissue of non-transgenic mice fed on a low-fat diet. Results are expressed as the means with their standard errors represented by vertical bars: ${ }^{*} P<0 \cdot 05,{ }^{*} P<0 \cdot 01$. (From Gnudi et al. 1995. Reproduced with permission from the Endocrine Society.)

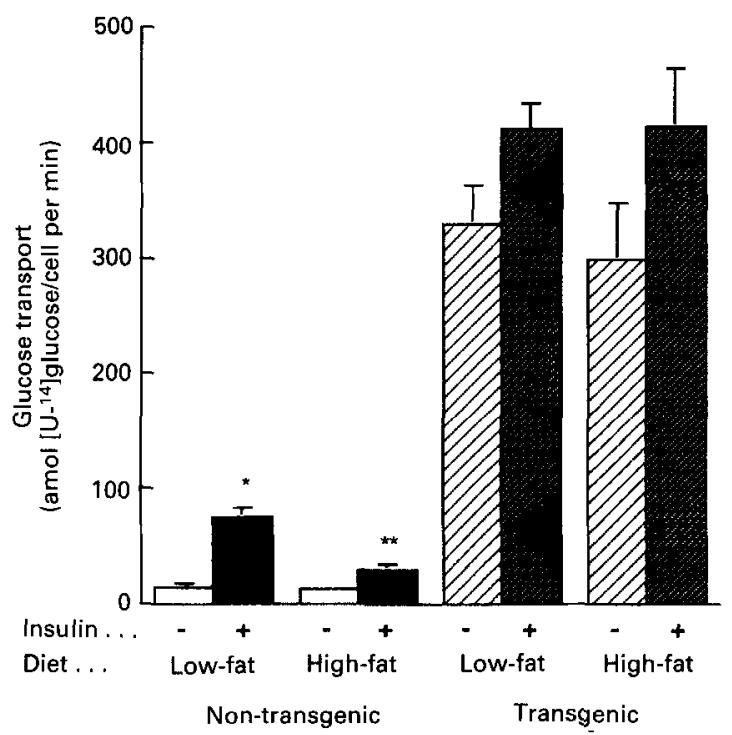

Fig. 3. Glucose transport in isolated adipocytes from non-transgenic and transgenic mice fed on either a low-fat or high-fat diet. Results are expressed as the means with their standard errors represented by vertical bars. In non-transgenic mice receiving the low-fat diet insulin-stimulated values were significantly different from basal levels: ${ }^{*} P<0 \cdot 01$. Insulin-stimulated values in non-transgenic mice receiving the high-fat diet were significantly different from insulin-stimulated values in non-transgenic mice receiving the low-fat diet: $* * P<0 \cdot 01$. Basal and insulin-stimulated glucose transport in transgenic mice receiving both the low-fat and high-fat diets were different from all non-transgenic mouse values $(P<0 \cdot 01)$. (From Gnudi et al. 1995. Reproduced with permission from the Endocrine Society.) 
activity. We find that altering the partitioning of glucose between muscle and fat diminishes the normal meal-induced stimulation of LPL activity in adipose tissue and reverses the inhibition of LPL activity in muscle (Gnudi et al. 1994). This could favour increased lipid oxidation by muscle and decreased accumulation of lipid stores in adipose tissue.

\section{SUMMARY}

In summary, over-expression of GLUT4 selectively in fat causes increased flux of glucose into adipocytes and leads to increases in either the replication of immature preadipocytes or their differentiation into mature adipocytes resulting in an increase in fat cell number. This is the first model in which obesity is accounted for entirely by adipocyte hyperplasia and, therefore, is useful for studying the mechanisms involved in controlling fat cell number in vivo.

GLUT4 over-expression in adipocytes of transgenic animals also increased wholebody insulin sensitivity. However, GLUT4 over-expression exclusively in adipocytes did not protect them from insulin resistance in vivo induced by high-fat feeding, in spite of the fact that insulin resistance was prevented at the level of the adipocyte. Interestingly, GLUT4 over-expression in fat protected the animals from developing further obesity when fed on a high-fat diet. It is possible that this failure to increase adiposity further is due to enhanced partitioning of glucose into fat, which may result in decreased glucose supply to muscle. This in turn may cause diversion of lipid to muscle to be oxidized as fatty acid. This diversion of lipid could result in protection against increased fat deposition in adipocytes.

Further studies will be required in order to understand the molecular mechanisms by which GLUT4 over-expression in adipose tissues affects nutrient partitioning between muscle and adipose tissue and what the consequences of this are for whole-body fuel metabolism.

This work was supported by National Institute of Diabetes and Digestive and Kidney Diseases Grant DK-43051 and grants from the Weight Watchers Foundation, the Diabetes Research and Education Foundation and the United States Department of Agriculture. P. R. S. was supported by an R. D. Lawrence Fellowship from the British Diabetic Association and L. G. by a JDF International Fellowship.

\section{REFERENCES}

Albert, B., Bray, D., Lewis, J, Raff, M., Roberts, K. \& Watson, J. D. (1989). Molecular Biology of the Cell. New York and London: Garlan Publishing, Inc.

Bell, G. I., Kayano, T., Buse, J. B., Burant, C. F., Takeda, J., Lin, D., Fukumoto, H. \& Seino, S. (1990). Molecular biology of mammalian glucose transporters. Diabetes Care 13, 198-208.

Brozinick, J. T., Etgen, G. J., Yaspelkis, B. B. \& Ivy, J. L. (1992). Contraction activated glucose uptake is normal in insulin resistant muscie of the obese Zucker rat. Journal of Applied Physiology 73, 382-387.

Butler, P. C., Kryshak, E. J., Marsh, M. \& Rizza, R. A. (1990). Effect of insulin on oxidation of intracellularly and extracellularly derived glucose in patients with NIDDM - Evidence for primary defect in glucose transport and/or phosphorylation but not oxidation. Diabetes 39, 1373-1380.

Cousin, B., Agou, K., Leturque, A., Ferre, P., Girard, J. \& Penicaud, L. (1992). Molecular and metabolic changes in white adipose tissue of the rat during development of ventromedial hypothalamic obesity. European Journal of Biochemistry 207, 377-382. 
DeFronzo, R. A. (1988). The triumvirate: beta cell, muscle, liver. Diabetes 37, 667-687.

Fink, R. I., Wallace, P., Brechtel, G. \& Olefsky, J. M. (1992). Evidence that glucose transport is rate limiting for in vivo glucose uptake. Metabolism 41, 897-902.

Friedman, J. E., Vente, J. E. D., Peterson, R. G. \& Dohm, G. L. (1991). Altered expression of muscle glucose transporter GLUT4 in diabetic fatty Zucker rats (ZDF/Drt-fa). American Journal of Physiology 261, E782-E788.

Gnudi, L., Jensen, D. R., Tozzo, E., Bliss, J. L., Heckel, R. H. \& Kahn, B. B. (1994). Altered regulation of lipoprotein lipase activity in adipose tissue and muscle of transgenic mice overexpressing GLUT4 selectively in fat. Diabetes 43, Suppl. 1, 133A.

Gnudi, L., Tozzo, E., Shepherd, P. R., Bliss, J. L. \& Kahn, B. B. (1995). High level overexpression of glucose transporter- 4 driven by an adipose-specific promoter is maintained in transgenic mice on a high fat diet, but does not prevent impaired glucose tolerance. Endocrinology 135, 995-1002.

Hainault, I., Guerre-Millo, M., Guichard, C.\& Lavau, M. (1991). Differential regulation of adipose tissue transporters in genetic obesity: selective increase in the adipose cell/muscle glucose transporter. Journal of Clinical Investigation $\mathbf{8 7}, 1127-1131$.

Kahn, B. B. (1992). Facilitative glucose transporters: regulatory mechanisms and dysregulation in diabetes. Journal of Clinical Investigation 89, 1367-1374.

Kahn, B. B. \& Pedersen, O. (1992). Suppression of Glut 4 expression in skeletal muscle of rats which are obese from high fat feeding but not from high carbohydrate feeding or genetic obesity. Endocrinology 132, 13-22.

Katz, A., Nyomba, B. L. \& Bogardus, C. (1988). No accumulation of glucose in human skeletal muscle during euglycemic hyperinsulinemia. American Journal of Physiology 255, E942-E945.

King, P. A., Horton, E. D., Hirshman, M. F. \& Horton, E. S. (1992). Insulin resistance in obese Zucker rat (falfa) skeletal muscle is associated with a failure of glucose transporter translocation. Journal of Clinical Investigation 90, 1568-1575.

Kraegen, E. W., James, D. E., Storlien, L. H., Burleigh, K. M. \& Chisholm, D. J. (1986). In vivo insulin resistance in individual peripheral tissues of the high fat fed rat: assessment by euglycaemic clamp plus deoxyglucose administration. Diabetologia 29, 192-198.

Pedersen, O., Kahn, C. R., Flier, J. S. \& Kahn, B. B. (1991). High fat feeding causes insulin resistance and a marked decrease in the expression of glucose transporters (Glut4) in fat cell of rats. Endocrinology 129, 771-777.

Pedersen, O., Kahn, C. R. \& Kahn, B. B. (1992). Divergent regulation of the Glut 1 and Glut 4 glucose transporters in isolated adipocytes from Zucker rats. Journal of Clinical Investigation 89, 1964-1973.

Penicaud, L., Ferre, P., Terretaz, J., Kinepanyan, M. F., Leturque, A., Dore, E., Girard, J., Jeanrenaud, D. \& Picon, L. (1987). Development of obesity in Zucker rats: early insulin resistance in muscle but normal sensitivity in white adipose tissue. Diabetes 36, 626-631.

Rothman, D. L., Shulman, R. G. \& Shulman, G. I. (1992). 31P nuclear magnetic resonance measurements of muscle glucose-6-phosphate. Journal of Clinical Investigation 89, 1069-1075.

Shepherd, P. R., Gnudi, L., Tozzo, E., Yang, H., Leach, F. \& Kahn, B. B. (1993). Adipose cell hyperplasia and enhanced glucose disposal in transgenic mice overexpressing GLUT4 selectively in adipose tissue. Journal of Biological Chemistry 268, 22243-22246.

Shepherd, P. R. \& Kahn, B. B. (1993). Cellular Defects in Glucose Transport: Lesson From Animal Models and Implications for Human Insulin Resistance, pp. 253-300 [D. Moller, editor]. Chichester: John Wiley.

Swinburn, B. A., Boyce, V. L., Bergman, R. N., Howard, B. V. \& Bogdardus, C. (1991). Deterioration in carbohydrate metabolism and lipoprotein changes induced by modern, high fat diet in Pima indians and Caucasians. Journal of Clinical Endocrinology and Metabolism 73, 156-165.

Thorens, B., Charron, M. J. \& Lodish, H. F. (1990). Molecular physiology of glucose transporters. Diabetes Care 13, 209-218.

Tozzo, E., Shepherd, P. R., Gnudi, L. \& Kahn, B. B. (1995). Transgenic Glut4 overexpression in fat enhances glucose metabolism: preferential effect on fatty acid synthesis. American Journal of Physiology 268, E956-E964.

Waddell, I. D., Zomerschoe, A. G., Voice, M. W. \& Burchell, A. (1992). Cloning and expression of a hepatic microsomal glucose transporter protein. Biochemical Joumal 286, 173-177.

Yki-Jarvinen, H., Sahlin, K., Ren, J. M. \& Koivisto, V. A. (1990). Localization of rate-limiting defect for glucose disposal in skeletal muscle of insulin-resistant type I diabetic patients. Diabetes 39, 157-167.

Yki-Jarvinen, H., Young, A., Lamkin, C. \& Foley, J. E. (1987). Kinetics of glucose disposal in whole body and across skeletal muscle in man. Journal of Clinical Investigation 79, 1713-1719. 
Zarjevski, N., Cusin, I., Vettor, R., Rohner-Jeanrenaud, F. \& Jeanrenaud, B. (1994). Intracerebroventricular administration of neuropeptide $\mathrm{Y}$ to normal rats has divergent effects on glucose utilization by adipose tissue and skeletal muscle. Diabetes $\mathbf{4 3}, 764-769$.

Zeil, F. H., Venkatesan, N. \& Davidson, M. B. (1988). Glucose transport is rate limiting for skeletal muscle glucose metabolism in normal and streptozotocin induced diabetic rats. Diabetes $\mathbf{3 7}, 885-890$. 